\title{
ASIA'S EXPERIENCE IN THE QUEST FOR A REGIONAL HUMAN RIGHTS MECHANISM
}

\author{
Sou Chiam*
}

"One World, One Dream"

The article outlines the development of a regional human rights charter in Asia. The article provides an historical overview of the efforts made to establish a charter, concluding that after fourteen UN workshops Asia still has not established any human rights mechanism. However, the author notes that some encouraging progress has been made. The article also identifies factors present in Asia that have hindered progress in establishing a regional mechanism and concludes with an outlook on how to proceed.

\section{INTRODUCTION}

In the run up to this year's Beijing Olympics, Tibetan activists scaled the Golden Gate Bridge in San Francisco to tie a "Free Tibet" banner next to the "One World, One Dream" banner. ${ }^{1}$ Human rights protection for Tibetans is only one of the many human rights challenges for the people of Asia. ${ }^{2}$ Asia is the only region in the world that does not have any region-wide human rights treaty or human rights mechanism directed towards the promotion and protection of human rights. ${ }^{3}$

* Sou Chiam is a human rights practitioner with an LLM from Cambridge University. She was a director of the Asia Pacific Forum for Women Law and Development and founding director of SUARAM, a human rights NGO. She was Senior Legal Counsel and Head of the Human Rights Policy Unit at the New Zealand Human Rights Commission. The author would like to acknowledge the insightful comments provided by Dato' Param Cumaraswamy towards the preparation of this paper.

$1 \quad$ New Zealand Herald (9 April 2008).

2 For the purposes of this paper, Asia includes states on the Asian continent and island states normally identified as Asian. Where Asia begins and ends is the subject of much discussion; see for example Watters and McGee Asia-Pacific: New Geographies of the Pacific Rim (Crawford House Publishing, Bathurst, 1997).

3 "Human Rights Herald" (July 2007) Publication of the Working Group for an ASEAN Human Rights Mechanism available at www.aseanhrmech.org. 
The quest for a regional mechanism in the form of a regional human rights court or commission to provide redress where national courts and institutions are unable or unwilling to provide justice is an ongoing quest (or just a dream) for many human rights practitioners in Asia. Since the 1960s there have been various initiatives by different groups to set up regional and sub-regional mechanisms in Asia. These initiatives have been driven mainly by human rights bodies of the United Nations. This article will give a brief history of UN initiatives to set up a regional human rights mechanism, discuss four main areas where positive progress is being made, four main factors that have hindered progress and conclude with what I see as the way ahead.

\section{UNITED NATIONS INITIATIVES}

\section{A The 1960s and 1970s}

In the 1960s a study group was set up by the UN Commission on Human Rights ("the Commission") to look into the establishment of regional human rights commissions in all parts of the world. In 1968 the Commission requested the UN Secretary General to organise regional seminars in those regions where there were no regional human rights commissions with a view to discussing their establishment. The UN General Assembly began to issue resolutions on regional arrangements for the promotion and protection of human rights in the 1970s. One such resolution 32/127(1977) included this appeal:

Appeals to states in areas where regional arrangements in the field of human rights do not yet exist to consider agreements with a view to the establishment within their respective regions of suitable regional machinery for the promotion and protection of human rights.

\section{B Colombo Seminar 1982}

In 1982, the UN organised a seminar called "National, Local and Regional Arrangements for the Promotion and Protection of Human Rights in the Asian Region" in Colombo, Sri Lanka. ${ }^{4}$ The seminar was attended by representatives from 19 states, regional organisations, non-government organisations (NGOs) and UN agencies. The conclusion reached by the participants stated, "the necessary political will, a prerequisite for evolving intergovernmental collaboration for the promotion of human rights, does not at present exist in the region." The participants felt that it was premature to think of a regional arrangement but recommended that periodic regional and subregional meetings should be held on human rights issues.

\section{Manila Workshop 1990}

The UN Centre for Human Rights organised the Manila workshop to cover both Asia and the Pacific. ${ }^{5}$ From this time onwards most of the UN initiatives covered Asia and the Pacific. The topic

4 Hidetoshi Hashimoto The Prospects for a Regional Human Rights Mechanism in East Asia (Routledge, London, 2004) 112.

5 Ibid, 112. 
of regional arrangements was only one of several topics covered. It was attended by representatives of 23 states from the Asia Pacific region. There were presentations describing the regional human rights mechanisms in Africa, Europe and the Americas. Some of the questions asked and discussions are summarised as follows:

(1) What are the advantages and disadvantages of a regional system?

It is easier to create a system within a homogenous group and such a system could go further and adopt even more stringent standards than the international system. As the Asia Pacific region is one of the least homogenous of world regions, other advantages would have to be explored.

(2) What happens when states refuse to abide by or ignore standards or decisions?

This varied according to the region as some are binding and some merely persuasive.

(3) What limitations do declarations of state of emergency and national security exemptions impose on regional arrangements?

This varies according to region. In Europe there is a power of judicial review to determine whether an emergency really exists.

(4) What happens in situations of conflict between national law and regional law?

In most cases, regional law will prevail.

(5) What is the extent of access and input by NGOs in the regional system?

For Europe, NGO access is significant.

Participants were concerned with whether there was a need for a regional mechanism, the effectiveness of such a mechanism, the role of NGOs and whether national sovereignty would be encroached upon.

\section{Jakarta Workshop 1993}

The second UN Workshop for the Asia Pacific Region on Human Rights Issues was held in Jakarta, Indonesia. It was attended by representatives of 28 states from the Asia Pacific region. ${ }^{6}$ The sessions on regional arrangements covered regional machinery and intra-regional co-operation, including bilateral exchange of information and practical assistance. The sessions tried to identify ways in which obstacles to the establishment of a regional human rights mechanism for the promotion and protection of human rights could be overcome. Key obstacles included:

6 Ibid, 113. 
(1) Asia and the Pacific are not homogeneous areas. There were pleas to be realistic and that plans for the establishment of a regional human rights mechanism should take into account the geographical complexity and vastness of the states that formed the regions;

(2) The cultural diversity, different historical backgrounds and levels of political stability, economic prosperity and social development;

(3) The lack of any unifying tradition; and

(4) The absence of high levels of mutual understanding between governments.

The Chairman's concluding remarks noted progress made at the sub-regional level and called for a "step by step" strategy. A first step could be the setting up of sub-regional machinery for human rights information dissemination, to be followed by establishing an "Asia Forum" to enhance regional exchange of ideas aimed at promoting human rights. He suggested that the Forum might be used later to design machinery at the sub-regional or regional level for the promotion and protection of human rights.

\section{E World Conference on Human Rights in Vienna 1993}

This was the first global conference to review the subject of human rights in the contemporary world. ${ }^{7}$ It produced the Vienna Declaration ${ }^{8}$ and Programme of Action, which were adopted by 171 states. Paragraph 37 states:

Regional arrangements play a fundamental role in promoting and protecting human rights. They should reinforce universal human rights standards, as contained in international instruments and their protection. ... The World Conference reiterates the need to consider the possibility of establishing regional and sub regional arrangements for the promotion and protection of human rights where they do not already exist.

Paragraph 76 further states "[t]he World Conference recommends that more resources be made available for the strengthening or the establishment of regional arrangements for the promotion and protection of human rights...".

\section{F Seoul Workshop 1994}

Representatives from 29 states from the Asia Pacific region participated in this workshop held in Seoul, South Korea. ${ }^{9}$ The three objectives of the workshop were to:

7 See www.unhchr.ch/huridocda/huridoca.usf and Param Cumaraswamy "The Universal Declaration of Human Rights - Is it Universal?" (15 ${ }^{\text {th }}$ LAWASIA Biennial Conference: "Law in a Changing Asia", Manila, Philippines, 30 August 1997) 5.

8 Vienna Convention on the Law of Treaties (27 January 1980) 1155 UNTS 331.

9 Hashimoto, above n 4, 113. 
(1) Explore possibilities for the establishment of regional arrangements for the promotion and protection of human rights;

(2) Review progress in the development of national institutions for the promotion and protection of human rights in the region; and

(3) Examine national action for promoting and protecting human rights, development of strategies for human rights education and means to encourage ratification of human rights treaties.

The Chairman's concluding remarks summed up participants' views as follows:

(1) Regional co-operation should begin at sub regional initiatives;

(2) There should be an annual UN Forum for the Asia and Pacific Region on Human Rights Issues as this will allow states in the region to benefit from initiatives taken at subregional and national level;

(3) The key to enhancing the human rights environment in Asia and the Pacific lies in the strengthening of implementation at the national level; and

(4) Development of a regional arrangement should be through a "building blocks" approach as this recognises that there are different "speeds" in the region, which required an evolutionary model.

The workshop noted the diverse cultural, historical and political backgrounds and the different levels of development in the region. It also noted that mutual respect among Asian and Pacific states would be the foundation to provide the opportunity for regional co-operation in human rights.

\section{G Kathmandu Workshop 1996}

The long-term objective of this workshop was to ensure the promotion and protection of human rights in the Asia and Pacific Region through the establishment of an effective regional human rights mechanism. ${ }^{10}$ The representatives of 30 states and 9 NGOs attended. For the first time states in West Asia, including Iran, Iraq, Jordan, Saudi Arabia, Syria, and United Arab Emirates participated. The workshop discussed common principles and explored enabling strategies for the establishment of a regional arrangement. The workshop conclusions included the following:

(1) Any regional arrangement would need to be based on the needs, priorities and conditions prevailing in the region;

10 Centre for Human Rights Geneva United Nations Report on the Fourth Workshop on Regional Human Rights Arrangements in the Asian and Pacific Region (Kathmandu, 26-28 February 1996). 
(2) The roles, functions and tasks of regional arrangements should be identified by the governments of the region;

(3) The diversities and complexities of the region would require extensive consultations among states in the region;

(4) The establishment of National Human Rights Institutions (NHRIs) by a number of Asian and Pacific countries was welcomed. States with existing NHRIs were encouraged to strengthen them as outlined in the Vienna Declaration and Programme of Action; and

(5) The useful roles played by NGOs in the promotion and protection of human rights and their participation in the process of the development of regional arrangements.

\section{H Amman Workshop 1997}

The Amman workshop was attended by representatives of 31 states. ${ }^{11}$ The following two key issues were agreed upon at the workshop:

(1) The development of a regional technical co-operation programme for the purpose of strengthening national and regional human rights capacities through the sharing of expertise, experiences and practices; and

(2) A process for designing the regional programme and future preparatory work towards developing a regional arrangement by establishing a working group.

The workshop endorsed the "step by step" approach, sharing information, the building of national capabilities and the establishment of confidence-building measures. It recognised that ratification of international human rights instruments was crucial. It recommended the creation of the Asia Pacific Forum of National Human Rights Institutions (APF) to support all independent national institutions in the region. It recognised the importance of NHRIs and civil society in the various steps towards regional arrangements. The workshop also reaffirmed that all human rights, civil and political, social and cultural, including the right to self-determination and the right to development, are universal, interdependent and indivisible.

\section{Tehran Workshop 1998}

The Tehran workshop was attended by representatives from 36 states, APF, NHRIs, NGOs, and UN agencies. ${ }^{12}$ It was noted that the Asia and Pacific Region was the only UN defined region without a specific human rights treaty and without some form of region-wide mechanism directed towards the promotion and protection of human rights. Some participants expressed caution about any hasty moves to establish a regional arrangement similar to those existing in other regions as the

11 See www.unhchr.ch/html/menu6/apw.htm and Hashimoto, above n 4, 115.

12 See www.unhchr.ch/huridoca.nsf and Hashimoto, above n 4, 115-116. 
diversity of the region makes it premature to establish a regional mechanism. Some participants went as far as saying that no currently existing regional arrangement could serve as an appropriate model for Asia Pacific. Participants did agree that technical co-operation aimed at national capacity building should be the foundation towards the establishment of a regional human rights mechanism. The workshop adopted a Framework for Regional Technical Co-operation in Asia Pacific (Tehran Framework) to develop:

(1) National Plans of Action and strengthening of national capacities;

(2) Human rights education;

(3) National institutions for the promotion and protection of human rights; and

(4) Strategies for the realisation of the right to development and economic, social and cultural rights.

\section{J New Delhi Workshop 1999}

The New Delhi workshop marked a turning point in the quest for a regional mechanism in the Asia Pacific region. ${ }^{13}$ The title of the Commission's annual resolutions changed from "Regional Arrangements for the Promotion and Protection of Human Rights in the Asia-Pacific Region" to "Regional Co-operation for the Promotion and Protection of Human Rights in the Asia-Pacific Region" as per Commission Resolution 1999/69 (1999). The paradigm shifted from the original aim of the UN Workshops to set up "Regional Arrangements" for a human rights mechanism to "Regional Co-operation".

The workshop participants committed to enhancing regional co-operation and to promoting universal respect for human rights by the step by step and building blocks approaches. It reaffirmed the universality, indivisibility, interdependence and inter-relatedness of all human rights and recognised that democracy, development and respect for human rights and fundamental freedoms are interdependent and mutually reinforcing. It affirmed the development of regional co-operation through the building of national capacities and exchange of experiences based on regional technical support of the UN Voluntary Fund for Technical Co-operation in the Field of Human Rights.

\section{K Beijing Workshop 2000}

The Beijing workshop focussed on regional co-operation in human rights rather than on regional arrangements. ${ }^{14}$ Mary Robinson as the High Commissioner for Human Rights said in Beijing that the workshop's priority was to:

13 Ibid. See also Hashimoto, above n 4, 116-117.

14 See www.unhcrc.ch/html/menu6/beijing. 
Review progress made in each of the four areas identified in Tehran and identify next steps in order to facilitate regional co-operation for the promotion and protection of human rights at the regional, subregional and national levels.

A Beijing Plan of Action to be implemented over two years was instituted to continue the activities under the Tehran Framework. I attended the workshop as a representative of the New Zealand Human Rights Commission. The conclusions reached emphasised the importance of undertaking activities under the Tehran Framework at national and sub-regional levels with the assistance of concerned states, NHRIs and civil society.

\section{Bangkok Workshop 2001}

At this workshop, there was an overview of initiatives towards regional human rights instruments for Asia and the Pacific. ${ }^{15}$ The overview gave examples of regional human rights instruments worldwide that included the European Convention for the Protection of Human Rights and Fundamental Freedoms, ${ }^{16}$ the American Convention on Human Rights, ${ }^{17}$ and the African Charter on Human and People's Rights. ${ }^{18}$

Mary Robinson reminded participants that the original reason of the UN workshops was to establish a regional human rights mechanism for Asia and the Pacific. She encouraged states to examine the possibility of establishing sub regional or regional human rights arrangements in the region. Professor Vitit Muntarbhorn gave an evaluation on the implementation of the Tehran Framework. States were encouraged to reinvigorate the Tehran Framework by revisiting its original intent to establish a regional human rights arrangement for Asia and the Pacific.

\section{Beirut Workshop 2002}

The tenth UN Workshop was held in Beirut, Lebanon. ${ }^{19}$ It was attended by representatives from 30 states. $^{20}$ States were called upon to take concrete steps to implement the Tehran Framework. Initiatives for the development of regional or sub-regional arrangements for the promotion and protection of human rights in the Asia Pacific region were reviewed. The workshop emphasised

15 See www.unhcrc.ch/html/menu6/bangkokover.htm.

16 European Convention for the Protection of Human Rights and Fundamental Freedoms (4 November 1950) 213 UNTS 222.

17 American Convention on Human Rights (22 November 1969) 1144 UNTS 143.

18 African Charter of Human Rights (27 June 1981) 1520 UNTS 217.

19 See www.unhcrc.ch/html/menu6/apw.htm, document E/CN.4/2002/WP3.

20 States attending included Australia, Bhutan, Brunei, China, Fiji, India, Indonesia, Iran, Iraq, Japan, Jordan, Kuwait, Lebanon, Malaysia, Mongolia, Myanmar, Nepal, New Zealand, Pakistan, Palestine, Philippines, Qatar, Korea, Saudi Arabia, Singapore, Solomon Islands, Sri Lanka, Syria, Thailand, Vietnam and Yemen. 
regional co-operation on various human rights issues and noted the regional workshop on the impact of globalisation on the full enjoyment of economic, social and cultural rights and the right to development held in Kuala Lumpur in May 2001. ${ }^{21}$

\section{N Islamabad Workshop 2003}

The eleventh UN Workshop was held in Islamabad, Pakistan. ${ }^{22}$ The workshop reviewed the progress in implementing the four pillars of the Tehran Framework and raised concerns about the limited resources available to the Office of the High Commissioner for Human Rights (OHCHR) to provide technical assistance on human rights issues and to protect and promote human rights in Asia Pacific. The workshop urged member states to support the human rights activities of the OHCHR in the region. The workshop noted the various human rights initiatives by the Association of Southeast Asian Nations (ASEAN) and the South Asian Association for Regional Co-operation (SAARC), for the strengthening and development of regional endeavours for the promotion and protection of human rights in Asia Pacific.

\section{O Doha Workshop 2004}

The twelfth UN Workshop was held in Doha, Qatar and was attended by 35 states, two intergovernmental organisations, 16 NHRIs, APF and seven NGOs. ${ }^{23}$ Activities relating to the Tehran Framework on national human rights action plans, NHRIs, human rights education and the right to development and social, economic and cultural rights were presented. A two-year action plan was adopted to implement the Tehran Framework. The Government of Qatar offered to host a UN Centre for Human Rights in South West Asia to support the development of national human rights capacities and infrastructure. The workshop noted the initiatives taken by countries of the region, including by the League of Arab States (Arab League), ASEAN and SAARC to strengthen regional or sub-regional endeavours for the protection and promotion of human rights. The workshop noted the financial and human constraints faced by the Pacific island states in their efforts to promote and protect human rights and asked the OHCHR to provide technical assistance, capacity building and training and the posting of a sub-regional representative in Fiji to support the Pacific island states.

21 I presented a paper titled "The Role of National Human Rights Institutions in relation to Globalisation and Children's Rights" on behalf of the Asia Pacific Forum of National Human Rights Institutions at the Kuala Lumpur regional workshop.

22 See www.unhchr.ch/html/menu6/islamabad.htm.

23 See www.unhchr.ch/html/menu6/dohaconclusions.doc. 


\section{P Beijing Workshop 2005}

The thirteenth UN Workshop was held in Beijing and was attended by 34 states, 17 NHRIs, APF, 13 international organisations and 13 NGOs. ${ }^{24}$ Louise Arbour, the UN High Commissioner for Human Rights, reminded participants that the main purpose of the many UN Workshops was to establish a regional framework for the promotion and protection of human rights. She had asked Professor Vitit Muntarbhorn to prepare a paper for the workshop to identify future directions for APF. Many of the useful suggestions made by Professor Muntarbhorn in his paper were noted. ${ }^{25}$ His suggestions included a high or ministerial level workshop, a five-year regional programme to integrate and operationalise various human rights initiatives in the Asia Pacific region, expand the space for NGOs and NHRIs to participate in the workshops and supporting the OHCHR regional offices in the Asia Pacific region.

For the first time, the workshop focused on a particular theme, "Human Rights and Human Trafficking". This was an important workshop as the Human Rights Resolution 2005/73 (2005) of the OHCHR was titled "Regional Arrangements for the Promotion and Protection of Human Rights" and reaffirmed that regional arrangement played an important role. Thus the paradigm shift in 1999 away from "regional arrangements" to "regional co-operation" was reversed.

\section{Q Bali Workshop 2007}

The fourteenth UN Workshop was held in Bali, Indonesia and was attended by 25 states and various sub-regional organisations, NHRIs, APF and NGOs. ${ }^{26}$ Professor Vitit Muntarbhorn gave a presentation entitled "Exploring the Window of Opportunities: Evolving a Framework for the Promotion and Protection of Human Rights in the Asia Pacific Region". It emphasised future challenges for the Asia Pacific Regional Framework, considered initiatives by regional organisations such as ASEAN to develop sub-regional arrangements, human rights mainstreaming in UN country programming and the expansion of OHCHR's field presence in the region. The theme discussed was "Human Rights and Extreme Poverty". The Bali Action Points consisted mainly of requests to the OHCHR to undertake the following:

(1) Summarise the recommendations of the regional workshops since the 1991 Manila Workshop;

(2) Compile a directory of resource materials and persons to support activities under the Regional Framework;

24 See www.hurights.or.jp/asia-pacific.

25 Vitit Muntarbhorn "In Search of the Rights Track: Evolving a Regional Framework for the Promotion and Protection of Human Rights in the Asia Pacific Region" (2007) 1 (10) Thailand Law Journal 1.

26 Human Rights Council Res 6/25 (28 September 2007); UNGA Res A/HRC/7/35 (7 January 2007). 
(3) Compile outcome documents of the four sub-regional workshops;

(4) Engage in consultations with states, regional organisations, NHRIs, civil society and other stakeholders on follow up activities under the Regional Framework; and

(5) Hold follow up consultations with other UN and multilateral development agencies to harness their resources in support of these activities.

The OHCHR identified regional priorities under its Human Rights Programme for Asia Pacific and continuation of its work within the Tehran Framework. In 2008, after fourteen UN Workshops, we have still not successfully established any human rights mechanism for Asia and the Pacific. However, there has been some positive progress towards the establishment of a human rights mechanism.

\section{POSITIVE PROGRESS IN FOUR MAIN AREAS}

\section{A Sub-Regional Initiatives}

In Asia, sub-regional inter-governmental organisations such as ASEAN, SAARC and the Arab League were not specifically set up to promote and protect human rights but are now making progress in that direction.

\section{ASEAN}

ASEAN $^{27}$ was set up in 1967 and it is made up of ten member states: Brunei, Cambodia, Indonesia, Laos, Malaysia, Myanmar, Philippines, Singapore, Thailand and Vietnam. On 20 November 2007, ASEAN leaders signed the ASEAN Charter which gave ASEAN a legal personality. The Charter calls for the establishment of an ASEAN human rights body for the "Promotion and protection of human rights and fundamental freedoms of peoples in ASEAN". There is a high-powered Working Group for an ASEAN Human Rights Mechanism (Working Group) whose primary goal is to establish an inter-governmental human rights commission for ASEAN. ${ }^{28}$ The Working Group's impetus came from the 1993 World Conference on Human Rights, which reiterated "the need to consider the possibility of establishing regional and subregional arrangements for the promotion and protection of human rights where they do not already exist". ${ }^{29}$ The Working Group recommends that the ASEAN human rights mechanism may include:

(1) A Declaration of Principles;

27 See www.aseansec.org.

28 See www.aseanhrmech.org.

29 Vitit Muntarbhorn "Roadmap for ASEAN Human Rights" (2003) Publication of the Working Group for an ASEAN Human Rights Mechanism 1, available at www.fnf.org.ph (accessed 1 June 2008). 
(2) A human rights commission with monitoring, promotional, and recommendatory functions. It may receive complaints from states and/or individuals. It may cover all rights or be issue specific. Another option is to have human rights commissions in all ASEAN member states and a mechanism can be worked out when they begin coordinating efforts; and

(3) A Human Rights Court that can deliver binding decisions.

The Working Group is a coalition of national working groups from ASEAN members, which include Government representatives, parliamentary human rights committees, the academia and NGOs. The three main reasons stated for why there is a need for an ASEAN human rights mechanism are:

(1) A human rights mechanism will ensure that ASEAN members will adhere to international human rights standards;

(2) The mechanism will provide a common platform where ASEAN members who are socio-politically different from each other, can articulate human rights concerns; and

(3) ASEAN as a region can cooperate to address human rights violations and collectively show its stand on human rights.

The terms of reference for the ASEAN Human Rights Body are yet to be determined by the ASEAN Foreign Ministers Meeting. The ASEAN Charter still has to be ratified by all ten ASEAN countries before it can come into force. The challenge for ASEAN leaders is to ensure that the ASEAN human rights body will have the capacity to provide timely and effective redress for human rights violations where the national setting is unable or unwilling to do so. A case in point will be to see how human rights violations in Myanmar are to be handled by the body.

ASEAN has adopted a number of human rights declarations:

(1) Jakarta Declaration on the Elimination of Violence Against Women in ASEAN Region (2004);

(2) ASEAN Declaration Against Trafficking in Persons particularly Women and Children (2004);

(3) Vientiane Action Programme (2004);

(4) Declaration on the Establishment of the ASEAN Charter (2005); and

(5) ASEAN Declaration on the Protection and Promotion of the Rights of Migrant Workers (2007). 
With a Charter, ASEAN is moving from a discretion-based organisation towards a rule-based one. ${ }^{30}$

There are concerns that some ASEAN member states may be uncomfortable with an ASEAN human rights body or are not yet ready for it. The ASEAN Vision 2020 upholds "Peace, Economic Development and Social Cohesion" for the region. Member states that are not ready to participate in the range of free trade agreements use the "ASEAN Minus X Formula" and may participate at a later stage. From a pragmatic point of view, the same formula may be used in relation to participation in the ASEAN human rights body.

\section{$2 S A A R C$}

SAARC $^{31}$ is made up of Bangladesh, Bhutan, India, Maldives, Nepal, Pakistan, and Sri Lanka. It currently does not have a human rights mechanism to deliver justice where the national setting is unable or unwilling to do so. It has a cooperative approach of focussing on treaties linked with specific human rights issues. In 2002, it adopted two treaties that impact on human rights: the SAARC Convention on Preventing and Combating Trafficking in Women and Children for Prostitution and the SAARC Convention on Regional Arrangements for the Promotion of Child Welfare in South Asia.

In 2004, SAARC adopted the SAARC Social Charter which impacts on many economic, social and cultural rights. There are commitments to eradicate poverty, improve health services, foster educational access, and promote the status of women and children, population stabilisation and drug addiction rehabilitation. Members set up national coordination committees through an integrated programme of action where core areas of co-operation are identified. SAARC has not moved to establish a South Asian human rights mechanism.

\section{The Arab League}

The Arab League ${ }^{32}$ is bound by Arab culture and not all of its 22 member states ${ }^{33}$ are in Asia. In 1994 the Arab Charter on Human Rights was finalised by the Arab League. This was the first inter-governmental treaty for parts of West Asia laying down human rights standards and a monitoring mechanism in the form of an Arab Human Rights Committee. There is a monitoring role for the Arab Human Rights Committee that can make recommendations of a persuasive nature.

30 Param Cumaraswamy "Implementing Human Rights in ASEAN" (ASEAN Civil Society Conference, Singapore Institute of International Affairs, 26-28 October 2007) 3.

31 See www.sarc-sec.org.

32 See www.arabji.com/ArabGovt/ArabLaegue.htm.

33 The Arab League states are Algeria, Bahrain, Comoros, Djibouti, Egypt, Iraq, Jordan, Kuwait, Lebanon, Libya, Mauritania, Morocco, Oman, Palestine, Qatar, Saudi Arabia, Somalia, Syria, Sudan, Tunisia, the United Arab Emirates and Yemen. 
Member countries have a reporting obligation. Although individual complaints cannot be currently made to the Committee, there is a possibility of protocols to add elements to the Arab Charter on Human Rights which could provide space for individuals to seek redress.

\section{B National Human Rights Institutions and the APF}

NHRIs are human rights organisations that have been established by national governments to promote and protect human rights. The first NHRIs were established in the 1970s. In 1991, a meeting of the Human Rights Commission in Paris agreed on a comprehensive set of principles to guide the operations of NHRIs in order to be effective. The "Principles Relating to the Status and Functions of National Institutions for the Promotion and Protection of Human Rights" (Paris Principles $)^{34}$ set out the minimum standards required to be an effective NHRI. The Paris Principles require that an effective NHRI has various characteristics, including:

(1) A clearly defined and broad based mandate, based on universal human rights standards;

(2) Independence guaranteed by legislation or the constitution;

(3) Autonomy from government;

(4) Pluralism, including membership that broadly reflects the society;

(5) Adequate powers of investigation into human rights breaches; and

(6) Sufficient resources.

The Paris Principles form the basis for accreditation at the international level by the International Coordinating Committee (ICC). $\mathrm{APF}^{35}$ and its network of NHRIs is considered by Professor Vitit Muntarbhorn to be "the closest that the Asia-Pacific region has come to a regional arrangement or machinery for the promotion and protection of human rights". ${ }^{36}$

NHRIs have a range of responsibilities. One of the most important is to receive complaints of unlawful discrimination or human rights abuses that breach national laws. NHRIs also raise community awareness and understanding of human rights, review national laws to ensure that they are consistent with international human rights standards and recommend law changes. At the New Zealand Human Rights Commission, one of my duties was to write submissions to the Parliamentary Select Committees on proposed legislation to ensure that international human rights standards were met.

34 "Principles Relating to the Status and Functioning of National Institutions for the Protection and Promotion of Human Rights" UNGA Res 48/134 (20 December 1993) [hereinafter Paris Principles].

35 See www.asiapacificforum.net.

36 Ibid. See also Muntarbhorn, above n 25, 7. 
APF was formed in 1996 and currently the full members include NHRIs from Afghanistan, Australia, India, Indonesia, Jordan, Malaysia, Mongolia, Nepal, New Zealand, Philippines, Korea, Sri Lanka, Thailand and Timor Leste. The Fiji Human Rights Commission was a full member until it resigned in 2007. APF provides technical assistance to strengthen existing NHRIs; gives assistance to governments and NGOs to help with the establishment of NHRIs and helps to develop regional co-operation on human rights.

The Advisory Council of Jurists (ACJ) was set up by the APF in 1998 to advise the APF on the interpretation and application of international human rights law. The ACJ is made up of eminent jurists from member states who consider references made to it by the APF. The ACJ has now developed a substantial body of regional jurisprudence on a wide range of human rights issues that include torture, trafficking, terrorism and the right to education. I had the privilege of supporting the ACJ in its inaugural session for the determination of the references on "Child Pornography and the Internet" and "The Death Penalty". The ACJ can be regarded as a "stepping stone" body, working towards the formation of a Asia Pacific Human Rights Court. APF and its NHRIs play a crucial role in human rights capacity building in the Asia Pacific region and are vital stakeholders to the formation of any mechanism for the region.

\section{Human Rights NGOs}

Human rights NGOs have played important roles in the quest for human rights mechanisms to protect human rights in Asia. There have been a number of NGO initiatives which I will discuss below.

The Law Association for Asia and the Pacific (LAWASIA) ${ }^{37}$ is a professional law association set up in 1966. One of its objectives is to promote and protect human rights. LAWASIA's Human Rights Standing Committee has been contributing towards the development of human rights mechanisms in the Asia Pacific region. The Committee organised a series of meetings among representatives of NHRIs, parliamentary human rights committees and human rights NGOs in the ASEAN region to discuss proposals for a human rights mechanism in Southeast Asia. These meetings led to the formation of the Working Group in 1996. ${ }^{38}$ LAWASIA also initiated efforts to set up a human rights mechanism in the South Pacific and was instrumental in the drafting of the Pacific Charter of Human Rights.

Another NGO initiative is that of Asian Human Rights Commission, ${ }^{39}$ a Hong Kong-based human rights NGO that promotes the Asian Charter of Human Rights. Over 200 NGOs participated

37 See www.lawasia.asn.au.

38 Carlos Medina "Background of the Working Group for an ASEAN Human Rights Mechanism" (1999) Human Rights Now 1.

39 See www.ahrc.org.hk. 
in the drafting of the Asian Human Rights Charter 1998. The Asian Human Rights Charter was declared in Kwangju, South Korea to coincide with the occasion of the fiftieth anniversary of the Universal Declaration of Human Rights. ${ }^{40}$ The Charter has been translated into many languages and is intended to be used as an educational document to develop solidarity for the promotion and protection of human rights in Asia.

In January 2001, the Association of Asian Parliaments for Peace (AAPP) considered a draft Charter of Human Rights for Asian Nations. There was only one public consultation on the draft Charter which was facilitated by UN Development Programme. Unfortunately the draft Charter was not adopted by the AAPP. ${ }^{41}$ The Asia Pacific Human Rights Network ${ }^{42}$ has members from various human rights NGOs and individual activists from across the Asia Pacific region. Currently they are working on issues of racism, disability rights and human trafficking across the region. They keep a close eye on development of NHRIs in the region.

The 1993 World Conference on Human Rights recognised the important role of NGOs in the promotion of human rights by their roles in increasing public awareness of human rights issues and training and research done to promote and protect human rights. The activities by NGOs will enhance the possibility of the setting up of a regional human rights mechanism for Asia. A regional human rights mechanism will make it easier for NGOs to assist individuals and groups to file human rights complaints when national courts are unable or unwilling to provide redress.

\section{Office of the High Commissioner for Human Rights}

In the OHCHR Strategic Management Plan 2008-2009, the High Commissioner stated: 43

The Asia Pacific region is also at an important point in the development of national and regional human rights infrastructure and mechanisms. Many countries in the region have national human rights institutions, although many of them lack capacity and several have had their independence and integrity compromised in recent years. ... The Asia Pacific Forum of National Human Rights Institutions has played an important role in fostering regional capacity in this area, and the ASEAN human rights commissions have begun to develop their own systems for transnational co-operation. Most importantly, for a region without its own human rights arrangements, ASEAN and, to a lesser extent, the Pacific Islands Forum, have begun to explore the possibility of creating sub regional frameworks and mechanisms.

40 Universal Declaration of Human Rights 1948 UNGA Res 217 (III), UN Doc. A/810 71.

41 See www.unhchr.ch/html/menu6/bankokover.htm.

42 See www.aphrn.org.

43 High Commissioner's Strategic Management Plan 2008-2009 available at www.ohchr.org 64. 
One of OHCHR's priority focuses is to strengthen institutions to protect human rights by supporting ASEAN and PIF in the creation of sub-regional human rights mechanisms. OHCHR will continue to work in close partnerships with APF and its NHRIs to ensure compliance with the Paris Principles and capacity to effectively investigate and seek redress for human rights violations.

The OHCHR has done much to establish and strengthen NHRIs. OHCHR runs advisory services and support regional initiatives related to NHRIs in all parts of the world, including in the Asia Pacific region. OHCHR also supports the international initiatives related to NHRIs by supporting the work of the ICC and the Sub-Committee on Accreditation of the ICC. It cooperates with other UN agencies and international and regional organisations on NHRIs.

The setting up of regional offices to cover South East Asia, South and West Asia and the Pacific enables the OHCHR to play a more hands-on role in promoting human rights in Asia and the Pacific. The regional office in Bangkok focussed on establishing an ASEAN human rights mechanism during 2006 and 2007 and will continue to provide technical support to establish a regional human rights mechanism within the ASEAN Charter. ${ }^{44}$

\section{FACTORS THAT HAVE HINDERED PROGRESS}

There have been many factors that have hindered progress in the quest for a human rights mechanism in Asia. These have included political issues such as the lack of political will and intergovernmental co-operation, cultural issues such as different value systems and languages, legal issues such as inadequate ratification of human rights treaties and state sovereignty and economic issues such as the vast economic disparity and development among Asian states.

\section{A Vastness and Diversity}

The UN High Commissioner for Human Rights, in her opening speech at the 13th UN Workshop in Beijing provided the following grim statistics for the creation of a human rights framework to protect and promote human rights in the Asia Pacific region: ${ }^{45}$

There are 52 countries in this vast region. Yet there are only fifteen national institutions or the like; only six national human rights action plans; the right to development remains elusive as does the ability of people in the region to claim their most basic economic and social rights - to water, to health, to housing, and so on. Only three of the 52 have ratified all seven core human rights treaties... I mention these facts simply to highlight the enormity of the challenge before us. I fully appreciate the difficulties in reaching consensus with regard to the establishment of a human rights mechanism to cover a region whose vastness is only matched by its diversity.

44 Ibid.

45 United Nations High Commissioner for Human Rights Opening Speech China Society for Human Rights Studies http://211.167.236.236/zt/magazine/200402006214140121.htm 3 (accessed 1 June 2008). 
As far back as the 1990 Manila Workshop, participants identified as a major obstacle the fact that Asia and the Pacific is not a homogenous area and that plans to establish a regional human rights mechanism will have to take into account the geographical complexity, diversity and vastness of the states in the region, as well as their different historical and cultural backgrounds and levels of political stability, economic prosperity and social development.

In spite of the vastness and diversity of Asia, states can work together to establish a regional human rights mechanism. The 1993 Vienna Declaration and Programme of Action states that: ${ }^{46}$

While the significance of national and regional particularities and various historical, cultural and religious backgrounds must be borne in mind, it is the duty of states regardless of their political, economic and cultural systems, to promote and protect human rights and fundamental freedoms.

\section{B Inadequate Ratification of Human Rights Treaties}

Many Asian states have not yet ratified the principal human rights treaties such as the International Covenant on Economic, Social and Cultural Rights, ${ }^{47}$ International Covenant on Civil and Political Rights, ${ }^{48}$ Convention on the Elimination of All Forms of Discrimination Against Women, ${ }^{49}$ Convention Against Torture and Other Cruel, Inhuman and Degrading Treatment or Punishment ${ }^{50}$ or the International Convention on the Elimination of All Forms of Racial Discrimination. ${ }^{51}$

Due to the lack of ratification, Asian states' commitment to protect and promote human rights to agreed international standards as set out in the UN Human Rights treaties is questionable. The Chinese Government argues that the right to subsistence is the most important of all human rights. A number of Asian states have used the argument that civil and political rights disrupt political stability and hinder economic development. ${ }^{52}$ It would be difficult to set up a regional human rights mechanism in Asia when states are not agreeable to a common standard.

46 Ibid. See www.unhchr.ch/huridocda/huridoca.usf.

47 International Covenant on Economic, Social and Cultural Rights (16 December 1966) 999 UNTS 2.

48 International Covenant on Civil and Political Rights (16 December 1966) 999 UNTS 171.

49 Convention on the Elimination of all Forms of Discrimination Against Women (18 December 1979) 1249 UNTS 13.

50 Convention Against Torture and other Cruel, Inhuman or Degrading Treatment and Punishment (10 December 1984) 1465 UNTS 85.

51 International Convention on the Elimination of all forms of Racial Discrimination (21 December 1965) 660 UNTS 195. See www2.ohchr.org/english/bodies/ratification.

52 Human Rights Watch Indivisible Human Rights The Relationship of Political and Civil Rights to Survival, Subsistence and Poverty (Human Rights Watch, New York, 1992). 
There has been a consistent lack of political will on behalf of many of the political leaders in Asia to ratify UN human rights treaties. To set up a workable regional mechanism for human rights in Asia will require all states in the region to agree to abide by a set of common human rights standards. Those political leaders who are unwilling to tolerate human rights and are determined to continue to build oppressive regimes in Asia where basic human rights are subordinated to other goals of the state will hinder the quest for a human rights mechanism for Asia.

The 1993 World Conference on Human Rights urged states to incorporate the standards contained in international human rights instruments into domestic legislation and to work towards the goal of universal ratification of international human rights treaties and protocols adopted within the framework of the UN system.

\section{The "Asian Values" Debate}

The various debates on "Asian values" and human rights have affected the quest to build human rights mechanism in Asia. Western notions of human rights are seen as excessively individualistic, as opposed to the emphasis on the family in Asian societies, and insufficiently supportive of religion and culture. Some Asian leaders such as Dr Mahathir Mohammed, the former Prime Minister of Malaysia, regarded the West as "morally decadent because of the growth of gay rights and relative success of the women's movement". ${ }^{53}$ Lee Kuan Yew of Singapore asserted that civil and political rights could hinder economic growth and development. ${ }^{54}$ At the 1993 World Conference on Human Rights, government officials from Singapore, China and other Asian countries entered into a tug of words with their American and European counterparts on the universality, inseparability and interdependence of civil and political rights and economic, social and cultural rights. ${ }^{55}$ Those states were critical of the international standards of human rights which they argued were Western standards. Liu Huaqui, the head of the Chinese delegation stated: ${ }^{56}$

The concept of human rights is a product of historical development. It is closely associated with specific social, political and economic conditions and the specific history, culture and values of a particular country. Different historical development stages have different human rights requirements. Countries at different development stages or with different historical traditions and cultural backgrounds also have different understanding and practice of human rights.

53 Chris Brown "Human Rights" in John Baylis and Steve Smith (eds) The Globalization of World Politics (2 ed, Oxford University Press, Oxford, 2001).

54 Fareed Zakaria "Culture is Destiny: A Conversation with Lee Kuan Yew" (1994) Foreign Affairs 73.

55 Marina Svensson "The Chinese Debate on Asian Values and Human Rights: Some Reflections on Relativism, Nationalism and Orientalism" in Michael Jacobsen and Ole Bruun (eds) Human Rights and Asian Values: Contesting National Identities and Cultural Representations in Asia (Nordic Institute of Asian Studies, Curzon, 2000).

56 James Tang Human Rights and International Relations in the Asia Pacific (Pinter, London, 1995). 
Part of the "Asian values" debate is based on cultural relativism versus universalism. Advocates of "Asian values" argue that international human rights norms are deeply imbedded in Western political tradition and therefore do not fit other cultures and societies. Some argue that the global human rights regime is largely commensurate with the Western cultural account, with its emphasis on such principles, policies and practices as individualism, liberal democracy and market capitalism and that non-Western states are "at a disadvantage in trying to promote and protect their distinctive cultural ideas by resisting the advance of Western culture". ${ }^{57}$

On the other hand, Kim Dae Jung, a former President of South Korea and the 2000 Nobel Peace Prize Laureate has stated that: ${ }^{58}$

Singapore's Lee Kuan Yew has suggested that the "Western concepts" of democracy and human rights will not work in Asia. This is false: Asia has its own venerable traditions of democracy, the rule of law, and respect for the people. Asia's destiny is to improve Western concepts, not ignore them.

A number of Asian human rights practitioners have argued that Asian governments which see international human rights standards as a Western construct and a form of Western imperialism do so in order to justify their poor records in the protection of human rights, especially civil and political rights.

The Asian Human Rights Charter rejects "Asian values" and cultural relativism and affirms the universality and indivisibility of human rights. It states "[w]e believe that rights are universal, every person being entitled to them by virtue of being a human being." Human rights standards as defined in various UN conventions are universal in character and since human rights derive from the dignity and worth inherent in the human person, they apply to all people regardless of culture or traditions.

\section{State Sovereignty}

The concept of state sovereignty is described as "supreme authority: to be sovereign is to be subject to no higher authority". ${ }^{59}$ Many Asian governments have insisted that human rights are within the domestic jurisdiction of a sovereign state. They insist that states can treat their citizens within their territory in any way they wish as a prerogative of state sovereignty. Any regional or international human rights mechanism to adjudicate or investigate human rights violations within a state may be viewed as a threat to state sovereignty.

57 Paul Close and David Askew Asia Pacific and Human Rights A Global Political Economy Perspective (Ashgate, United Kingdom, 2004).

58 Dae Jung Kim "Is Culture Destiny? The Myth of Asia's Anti-Democratic Values" (1994) Foreign Affairs 1. See also http://foreignaffairs.org.

59 Jack Donnelly Universal Human Rights in Theory and Practice (2 ed, Cornell University Press, Ithaca, 2003) and Daniel Philpott "Ideas and the Evolution of Sovereignty" in State Sovereignty, Change and Persistence in International Relations (University Park: Pennsylvania State University Press, United States, 1997). 
Using the traditional concept of state sovereignty, the Chinese Government has maintained that human rights belong to its domestic jurisdiction as a sovereign state and it has a policy of noninterference in the domestic affairs of other states. ${ }^{60}$ Many Asian states use the sovereignty argument to reflect criticisms of their own poor human rights records. They use the principle of noninterference when they take no action against neighbouring Asian states which abuse human rights. Such states are therefore reluctant to support the establishment of any regional human rights mechanism that could expose them to complaints of human rights violations filed by their citizens, NGOs, and other states in the region. Some states are not willing to be subjected to a higher authority like a regional human rights court.

Kofi Annan, former UN Secretary General, has argued that human rights should not be abridged in the name of state sovereignty. He stated: ${ }^{61}$

There is no one set of European rights, and another of African rights. Human rights assert the dignity of each and every individual human being, and the inviolability of the individual's rights. They belong inherently to each person, each individual and are not conferred by, or subject to, any governmental authority. There is no one law for one continent, and one for another. And there should be only one single standard - a universal standard - for judging human rights violations.

\section{THE WAY AHEAD}

The quest for a regional human rights mechanism in Asia is a continuing one. The world is getting more interdependent due to the globalisation of the world economy. What happens in one state affects other states due to the interdependence of the world in which we live in. There is rapid progress in mass communication and internet technologies. State boundaries are no longer able to continue to keep out the flow of information and influence public opinion. Governments have become less the masters of what occurs even within their physical boundaries, even though they claim state sovereignty.

International human rights treaties represent moral interdependence. Internationally recognised human rights standards are applicable irrespective of political, economic or cultural diversity. Human rights standards are comprehensive as they encompass economic, social and cultural rights and also civil and political rights. The efforts to promote and protect human rights will need regional and international co-operation because cooperative efforts are more efficient than separate ones in this increasingly interdependent world.

60 Seth Harris "Asian Human Rights: Forming a Regional Covenant" (2000) Asia Pacific Law \& Policy Journal 17:13, 17:16.

61 Kofi Annan "Address by the UN Secretary General to the Foreign Institute of the Paasiviki Association" (Helsinki, 13 August 1997). 
APF and NHRIs play a vital role in promoting and protecting human rights in Asia and the Pacific. China and Japan still do not have NHRIs. China's growing economic and political influence over states in Asia means that it is important to get China involved in upholding human rights and participating actively in the quest for a regional human rights mechanism.

The setting up of an ASEAN human rights mechanism will be a step in the right direction in the quest for an Asian human rights mechanism. There is considerable movement towards economic integration in Asia through free trade agreements. In November 2004, the leaders of ASEAN+3 (10 ASEAN countries plus China, Japan and Korea) agreed to establish an "East Asian Community" which aims include the establishment of an East Asian Free Trade Area. In November 2007, the East Asia Summit, comprising the leaders of ASEAN+6 (namely, ASEAN+3 plus Australia, India and New Zealand) met in Singapore to discuss common issues such as Avian flu, education, finance and natural disasters. The East Asia Summit is considered "an integral part of the overall evolving regional architecture". ${ }^{62}$ I believe that stronger economic integration in Asia will assist towards the quest for a region wide human rights mechanism.

The "step by step" and "building blocks" approaches towards the establishment of a regional human rights mechanism as advocated in the various UN Workshops described earlier require regional vision, leadership and mutual co-operation. It may be that the establishment and success of sub-regional human rights mechanisms such as an ASEAN human rights mechanism to promote and protect human rights will lead to the path to fulfil the quest for a region wide human rights mechanism sometime in the future.

62 Masahiro Kawai and Ganeshan Wignaraja "Regionalism as an Engine of Multilateralism: A Case for a Single East Asian FTA" (Asian Development Bank Working Paper Series on Regional Economic Integration, 2008) 14. 